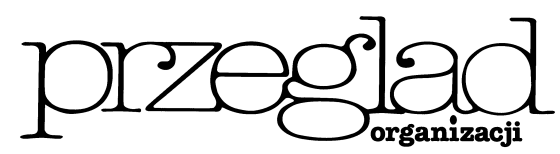

\title{
Wpływ programów punktowych na lojalność klientów
}

https://doi.org/10.33141/po.2005.12.08

Edyta Rudawska
Przegląd Organizacji, Nr 12 (791), 2005, ss. 32-35

www.przegladorganizacji.pl Towarzystwo Naukowe Organizacji i Kierownictwa (TNOiK)

\section{Programy lojalnościowe w służbie lojalności}

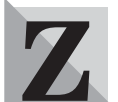

opinii menedżerów firm działających w Polsce, jak i w krajach zachodnich wynika, że zdobycie i utrzymanie lojalności klientów jest już od dłuższego czasu priorytetowym wyzwaniem stojącym przed zarządzanymi przez nich firmami. W krajowych przedsiębiorstwach czynnik ten plasuje się na pierwszym miejscu, natomiast $\mathrm{w}$ zagranicznych na trzecim, zaraz po trwałym i stałym wzroście przychodów oraz szybkości, elastyczności działania i zdolności do zmian ${ }^{1)}$. Powyższe dane pozwalają stwierdzić, że przedsiębiorstwa zareagowały na zmiany sytuacji rynkowej walką i koncentracją na kliencie. Szukając recepty na lojalność firmy dokonują coraz bardziej wyrafinowanej segmentacji rynku, starają się powiązać ofertę z wartością poszczególnych klientów czy zaoferować im tzw. programy lojalnościowe. Mimo że poziom nasycenia krajowego rynku tego typu działaniami jest jeszcze niższy niż w Europie Zachodniej, ich liczba w Polsce dynamicznie rośnie. Obecnie połowa polskich przedsiębiorstw posiada program lojalnościowy. Wprowadzając je firmy stawiają sobie następujące cele ${ }^{2)}$ :

- zwiększenie udziału w rynku,

- obniżenie wskaźnika klientów rezygnujących z ich usług,

- uzyskanie informacji marketingowej o uczestnikach,

- sterowanie zachowaniami klientów.

Programy lojalnościowe obejmują różnorodne działania, począwszy od kart stałego klienta poprzez kupony, doradcze kluby konsumenta, czasopisma firmowe, listy firmowe do klientów, gorące linie telefoniczne na punktowych programach promocyjnych, tzw. programach bonusowych, skończywszy. Z badań prowadzonych przez firmę Roland Berger Strategy Consultants $^{3)}$ wynika, że w Polsce najczęściej stosowanym narzędziem są właśnie te ostatnie. Polegają one na gromadzeniu punktów w zamian za korzystanie z usług lub nabywanie produktów i późniejszej ich wymianie na nagrody. 53\% firm oferuje swoim klientom programy punktowe, co piąta karty klienta, niewiele mniej, bo $18 \%$ kluby klienta. Sporadycznie natomiast stosowane są pozostałe narzędzia. Potwierdzeniem tej sytuacji są w pewnym sensie badania firmy ContactPoint, prowadzone z kolei wśród uczestników programów lojalnościowych ${ }^{4}$. Wynika z nich, że największa część, bo aż $73 \%$ respondentów uczestniczy właśnie w programach punktowych.

\section{Co o punktowych programach lojalnościowych sądzą ich uczestnicy}

W

obliczu tak dużej powszechności programów bonusowych należałoby zbadać, na ile są one skuteczne, jeśli chodzi o ich wpływ na lojalne postawy klientów. Wyniki badań na ten temat ${ }^{5)}$ skłaniają do refleksji, że tego typu działania promocyjne póki co nie stanowią skutecznego narzędzia budowania lojalności klientów, a sami ankietowani nie mająjednoznacznie sprecyzowanej opinii na temat roli programów bonusowych w procesie budowania relacji z klientami.

$\mathrm{Z}$ jednej strony zapytani o to, co w największym stopniu wpływa na ich satysfakcję i przywiązanie do firmy, z usług której korzystają, wskazywali najczęściej na bliską lokalizację, przystępne ceny oraz miła obsługę (wykres 1). Programy lojalnościowe uplasowały się dopiero na piątym miejscu.

Co jeszcze ważniejsze, w aspekcie prowadzonych rozważań na temat skuteczności programów lojalnościowych, o ile zdecydowana większość respondentów deklaruje swój zamiar korzystania z usług danej firmy po zakończeniu programu lojalnościowego, to jednak powodem tego nie wydaje się być przywiązanie do firmy i lojalność, lecz zwykła wygoda wynikająca właśnie z korzystnej lokalizacji firmy (wykres 2).

$\mathrm{Z}$ drugiej strony, ankietowani jednak wskazują, że programy lojalnościowe mogą stanowić narzędzie budowania bliskich relacji pomiędzy firmą a jej klientami. Niemal połowa uczestników zadeklarowała, że tego typu działania sprawiają, że korzystają z usług firmy tylko go oferującej, co niewątpliwie jest jedną z oznak przywiązania klienta do firmy (wykres 3).

$\mathrm{O}$ niewątpliwie rosnącej roli programów lojalnościowych w procesie budowy trwałych relacji z klientami świadczy również fakt, że niemal 3/4 osób uważa, że mogą one pomóc w budowaniu emocjonalnej więzi między klientem a firmą (wykres 4). Podczas gdy co piąty respondent nie ma na ten temat zdania, to zaledwie co dziesiąty się $\mathrm{z}$ nim nie zgadza.

Procentowy rozkład odpowiedzi pokazuje również, że osoby biorace udział w badaniu maja przychylny stosunek do programów bonusowych (tabela 1). Zdecydowana większość uważa bowiem, że są one miłym dodatkiem i mogą stanowić dodatkową wartość otrzymaną przez klientów. Mogą również być istotnym elementem wyróżniającym firmę od konkurencji. Bardzo nieliczna grupa uznaje te programy za denerwujące i uprzedzające do firmy. 


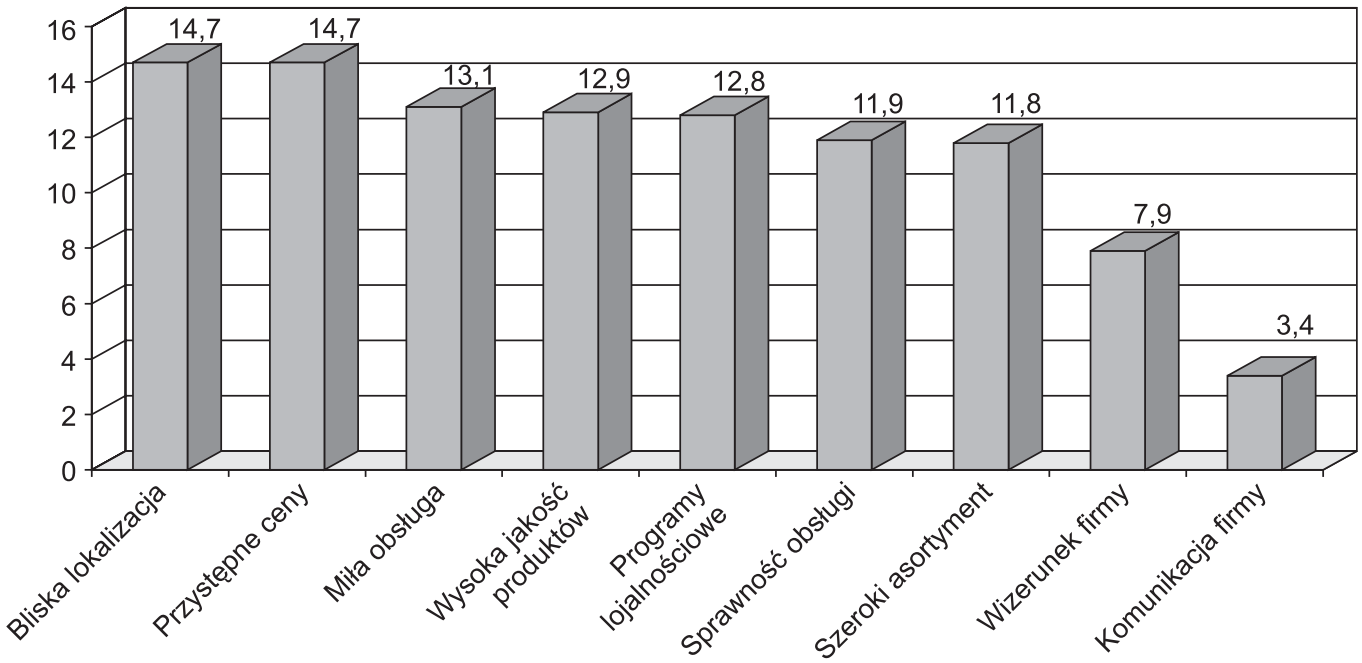

Wykres 1. Czynniki wpływające w największym stopniu na satysfakcję i przywiązanie klientów (\% wskazań)

Źródło: opracowanie własne na podstawie przeprowadzonych badań.

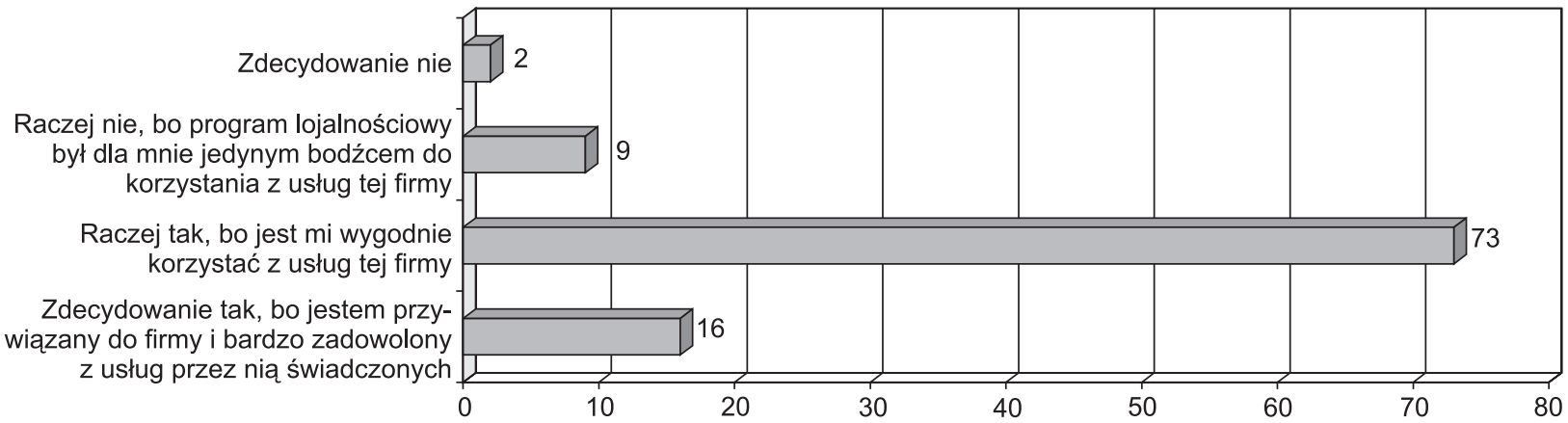

Wykres 2. Czy po zakończeniu programu lojalnościowego pozostaną Państwo nadal klientami danej firmy? (\% wskazań)

Źródło: opracowanie własne na podstawie przeprowadzonych badań.
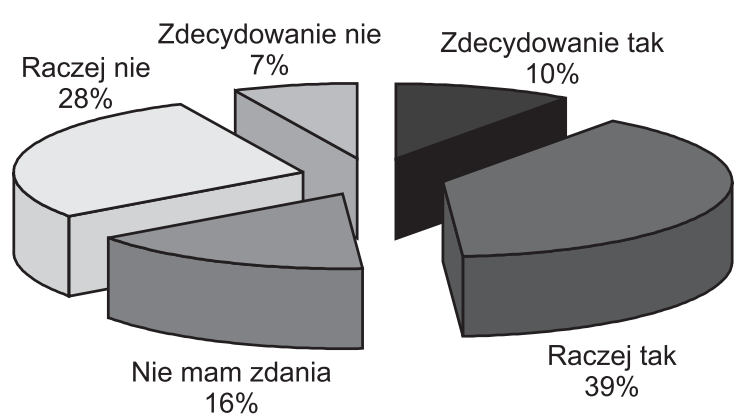

Wykres 3. Czy program lojalnościowy sprawia, że korzystają Państwo z usług tylko firmy, która go oferuje? (\% wskazań)

Źródło: opracowanie własne na podstawie przeprowadzonych badań.

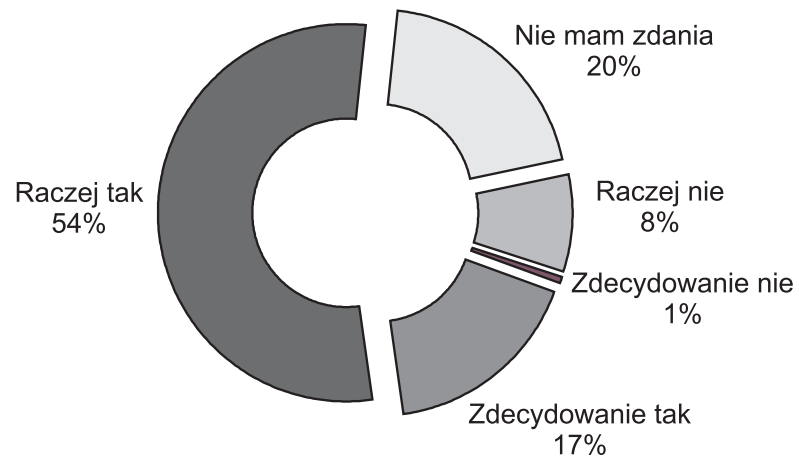

Wykres 4. Czy uważają Państwo, że programy lojalnościowe mogą pomóc $w$ budowaniu emocjonalnej więzi między klientem a firmą?

Źródło: opracowanie własne na podstawie przeprowadzonych badań. 
Tab. 1. Stosunek respondentów do wskazanych stwierdzeń (\% wskazań)

\begin{tabular}{|l|c|c|c|c|c|}
\hline \multicolumn{1}{|c|}{ Programy lojalnościowe: } & $\begin{array}{c}\text { Całkowicie } \\
\text { się zgadzam }\end{array}$ & $\begin{array}{c}\text { Zgadzam } \\
\text { się }\end{array}$ & $\begin{array}{c}\text { Trudno } \\
\text { powiedzieć }\end{array}$ & $\begin{array}{c}\text { Nie } \\
\text { zgadzam się }\end{array}$ & $\begin{array}{c}\text { Całkowicie } \\
\text { się nie } \\
\text { zgadzam }\end{array}$ \\
\hline Przywiązują do firmy & 22,4 & 46,8 & 19,4 & 10,3 & 1,2 \\
\hline Są miłym dodatkiem & 33,3 & 56,7 & 5,98 & 3,7 & 0,3 \\
\hline Są mi obojętne & 3,3 & 11,2 & 29,5 & 46,5 & 9,4 \\
\hline Denerwują mnie & 2,7 & 5,1 & 16,5 & 49,5 & 26,1 \\
\hline Zniechęcają mnie, uprzedzają do firmy & 2,3 & 5,7 & 17,4 & 41,6 & 32,9 \\
\hline Stanowią jedynie formę dobrej zabawy & 7,6 & 36,7 & 28,5 & 23,5 & 3,5 \\
\hline $\begin{array}{l}\text { Stanowią istotny element wyróżniający firmę } \\
\text { od konkurencji }\end{array}$ & 10,9 & 48,2 & 21,5 & 17,1 & 2,2 \\
\hline $\begin{array}{l}\text { Stanowią dodatkową wartość otrzymywaną } \\
\text { przez klientów }\end{array}$ & 15,5 & 55,1 & 19,5 & 6,99 & 2,9 \\
\hline
\end{tabular}

Źródło: opracowanie własne na podstawie przeprowadzonych badań.

Mając na uwadze pozytywny stosunek uczestników programów lojalnościowych do tego typu działań promocyjnych należy przypuszczać, że jeśli będą właściwie stosowane, będą mogły stanowić efektywne i zarazem skuteczne narzędzie budowania trwałych relacji z klientami.

\section{Dlaczego programy bonusowe w obecnej formie nie mają szansy na przetrwanie jako narzędzie budowania trwałych związków z klientem}

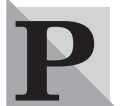

rezentowane wyniki badań pozwalają zauważyć, że programy kuponowe są skuteczne, jeśli potraktuje się je jako narzędzie zwiększenia aktywności zakupowej klientów. Tak rozumiane programy lojalnościowe w dłuższej perspektywie nie maja jednak szansy na przetrwanie, przynajmniej na niektórych rynkach, z dwóch głównych powodów.

- Dynamicznie rosnacy poziom nasycenia instrumentami lojalnościowymi, w tym również programami punktowymi, może doprowadzić do znudzenia wśród klientów i w rzeczywistości spowoduje, że dokonując wyboru firmy, nie będą kierowali się możliwością zdobycia punktów (wszędzie w zasadzie będą mogli je otrzymać).

- Niewłaściwy sposób organizacji programów lojalnościowych powoduje, że o ile mogą one wpływać na wzrost wielkości zakupów w danej firmie w określonym czasie, to w rzeczywistości nie służą do zjednywania i utrzymywania lojalności klientów.

Pewne działania, które podejmują firmy, aby zbudować więzi z klientami, są często tym, co je niszczy. Dzieje się tak dlatego, że są źle stosowane. Według firmy doradczej Roland Berger Strategy Consultants, najczęściej pojawiające się błędy popełniane podczas opracowania programu lojalnościowego prowadzące do jego niepowodzenia tkwią w:

- braku zaangażowania w program wszystkich działów firmy,

- zbyt małej liczbie nagród w stosunku do uczestników programu,
- wolnej realizacji obiecanych korzyści (nawet najbardziej atrakcyjna nagroda oddalona w czasie traci na sile przyciagania),

- zbyt skomplikowanym sposobie komunikacji na temat programu,

- oczekiwaniu przez przedsiębiorstwo natychmiastowych korzyści z programu i niedocenianiu kosztów związanych $\mathrm{z}$ oferowaniem i administracja programów lojalnościowych (firmy, projektując programy, często koncentrują się na nagrodach dla klientów i korzyściach dla firmy, ignorując koszty takiej aktywności). Sa one jednak niemałe, a wynikaja z kosztów nagród, działań marketingowych, inwestycji w infrastrukturę i sprzęt informatyczny oraz administracji programu $^{6)}$.

Wydaje się, że równie ważną przyczyną niepowodzeń programów jest zbyt proste ich rozumienie i traktowanie jako jedynego narzędzia budowania trwałych relacji z klientami. Tymczasem jest to zaledwie skromny wycinek całościowej strategii firmy, swego rodzaju kultury organizacyjnej nakierowanej na budowanie więzi z klientami.

Błędy, które firmy często popełniają, opracowując programy lojalnościowe, związane są również ze zbyt wąskim sposobem rozumienia korzyści dla klienta, ograniczającym je do tych o charakterze materialnym. Mając na uwadze duży stopień złożoności potrzeb klientów trzeba pamiętać, że nie zawsze spodziewają się oni tego typu korzyści. W dodatku lojalność wynikająca z gratyfikacji natury ekonomicznej, zwana w literaturze lojalnością cenową i bodźcową ${ }^{7}$, kończy się z chwilą, gdy konkurent zaoferuje korzyści o większej wartości. Stosowanie tak rozumianych programów może doprowadzić jedynie do osiągnięcia pierwszego $\mathrm{z}$ trzech poziomów relacji $\mathrm{w}$ hierarchii zaproponowanej przez L. Berry'ego i A. Parasuramana ${ }^{8}$.

Chodzi o relacje oparte na cenie i związane z oferowaniem klientom nowych wartości o charakterze finansowym. Staja się one tym samym jedynie bariera ekonomiczną zapobiegającą zmianie firmy na konkurencyjną. Nietrudno się domyślić, że tego rodzaju bariere można łatwo pokonać, szczególnie jeśli weźmie się pod uwagę lawinowy wzrost konkurencyjnych pro- 
Tab. 2. Trzy poziomy relacji

\begin{tabular}{|l|c|c|c|}
\hline \multicolumn{1}{|c|}{ Poziom } & Pierwszy & Drugi & Trzeci \\
\hline Typy więzi & Finansowe & Finansowe i społeczne & $\begin{array}{c}\text { Finansowe, społeczne } \\
\text { i strukturalne }\end{array}$ \\
\hline Orientacja marketingowa & Nabywca & Indywidualny klient & Indywidualny klient \\
\hline $\begin{array}{l}\text { Stopień indywidualizacji } \\
\text { obsługi }\end{array}$ & Niski & Średni & $\begin{array}{l}\text { Od średniego } \\
\text { do wysokiego }\end{array}$ \\
\hline $\begin{array}{l}\text { Najważniejszy element } \\
\text { marketingu mix }\end{array}$ & Cena & Komunikacja osobista & $\begin{array}{c}\text { Zindywidualizowane } \\
\text { dostarczanie usług }\end{array}$ \\
\hline $\begin{array}{l}\text { Możliwości osiąnnięcia trwałej } \\
\text { przewagi konkurencyjnej } \\
\text { poprzez zróżnicowanie }\end{array}$ & Niskie & Średnie & Wysokie \\
\hline
\end{tabular}

Źródło: J. OTTO, Programy lojalnościowe metoda przeciwdziatania utracie klientów, „Wiadomości Ubezpieczeniowe” 2001, nr $9-10$, s. 5 .

gramów. Nie umożliwiają one natomiast budowania bardziej trwałych i tym samym trudniejszych do zerwania relacji o charakterze społecznym, kiedy nabierają bardziej osobistego charakteru dzięki indywidualizacji komunikacji i obsługi klienta (drugi poziom) oraz tych obejmujacych dodatkowo związki strukturalne, związane z oferowaniem usług niedostępnych u konkurentów, bazujących na pełnym zaufaniu klienta do firmy (trzeci poziom).

\section{Zakończenie}

K. Czupryna, z firmy Nova Communication Group, powiedział: „lojalności klientów nie można kupić nigdy. Można tylko próbować ją zdobyć”. Mając to na uwadze słuszne jest uświadomienie sobie, że same programy punktowe koncentrują się raczej wokół kupowania lojalności. Próba jej zdobycia natomiast wymaga od sprzedającego takiego samego zaangażowania się w proces decyzyjno-zakupowy klienta, jak w dostarczanie mu coraz lepszych usług. Wszelkie próby podejmowane w celu zdobycia lojalności klientów wymagają dokonania znaczących zmian w organizacji prowadzonej działalności i zwrócenia uwagi na następujace elementy. Po pierwsze, koncentrację na klientach najbardziej opłacalnych dla firmy ${ }^{9}$. Nie wszyscy klienci są bowiem równi z punktu widzenia osiąganej zyskowności. W związku z tym należy wyodrębnić grupę klientów najbardziej opłacalnych, a następnie opracować strategię pozwalająca na wykreowanie lojalności. Po drugie, przygotowanie strategii lojalności klientów. Tutaj między innymi znaczącą rolę będą odgrywały programy lojalnościowe, w tym właśnie programy punktowe. Po trzecie, poprawę procesu obsługi klientów. Wszelkie formy kontaktu klienta (np. załatwianie reklamacji, obsługa przy okienku czy przez telefon) powinny być bowiem tak zorganizowane, aby wspierały wybraną strategię lojalności. Po czwarte, wspieranie pracowników liniowych. Powodzenie systemu jest uwarunkowane wsparciem, odpowiednia postawą i aktywnym uczestnictwem wszystkich pracowników, a w szczególności pracowników liniowych. Po piate wreszcie, systematyczne monitorowanie prowadzonej działalności. Obejmuje ono pomiar zadowo- lenia klienta i pozyskanie informacji zwrotnej w celu dalszego jej wykorzystania w procesie modyfikacji realizowanego systemu zarządzania lojalnością.

dr Edyta Rudawska

Katedra Marketingu

Uniwersytet Szczeciński

\section{PRZYPISY}

1) K. OBŁÓJ, M. ZDZIARSKI, Wyzwania stojace przed prezesami firm w 2005 roku, „Harvard Business Review Polska”, listopad 2004, s. 18.

2) Polskie programy lojalnościowe, www.egospodarka.pl, $\mathrm{z}$ dnia 20.05.2004.

3) Roland Berger Strategy Consultants przeprowadził badanie w listopadzie 2003 roku. Objeto nim 110 polskich przedsiębiorstw kierujących swoją ofertę do klientów indywidualnych, tj.: ogólnopolskie sieci drogerii, domy wysyłkowe, serwisy e-commerce, ogólnopolskie sieci usługowe, sieci stacji paliw, sieci sklepów z elektroniką użytkową, producenci telefonów komórkowych, firmy odzieżowe, banki, linie lotnicze, hotele, supermarkety itp.

4) ContactPoint to outsourcingowe call center, wykonujące badania CATI, a także zajmujące się obsługą programów lojalnościowych. Badanie opinii konsumentów, odnośnie do działań promocyjnych określanych łącznie mianem programów lojalnościowych, zostało przeprowadzone przy wykorzystaniu telefonu wśród 463 losowo wybranych osób województwa mazowieckiego; www.WirtualneMedia.pl

5) Badania zostały zrealizowane pod kierunkiem autorki przez studentów IV roku kierunku „Zarzadzanie i Marketing”, w ramach przedmiotu „Zarządzanie relacjami z klientami”. Badanie zostało przeprowadzone metoda wywiadu osobistego opartego na kwestionariuszu ankiety w 2004 roku. Respondentami badania byli mieszkańcy Szczecina, osoby, które korzystały przynajmniej z jednego punktowego programu lojalnościowego. W wyniku wstępnej weryfikacji otrzymanych ankiet i odrzuceniu kwestionariuszy błędnie wypełnionych lub niekompletnych do analizy statystycznej przyjęto 348 ankiet.

6) Szerzej na temat kosztów: Programy lojalnościowe, „Global Business. Nowości Światowej Literatury Biznesu w syntetycznych opracowaniach" 2001, $\mathrm{nr} 1$.

7) Szerzej na temat rodzajów lojalności zob.: B. KARAŚ, Przywiazanie klienta, „MpK-T” 2004, nr 57.

8) L. BERRY, A. PARASURAMAN, Marketing Services Competing Through Quality, Free Press, New York 1991, s. 137.

9) Szerzej na ten temat zob.: E. RUDAWSKA, Lojalność klientów, PWE, Warszawa 2005. 